\title{
PENGEMBANGAN MODUL FISIOLOGI TUMBUHAN BERORIENTASI KONSTRUKTIVISME DILENGKAPI PETA PIKIRAN
}

\author{
Lia Angela \\ Institut Agama Islam Negeri (LAIN) Kerinci \\ email: liaangela@iainkerinci.ac.id
}

\begin{abstract}
Students need a lecture material that can help and facilitate them in lectures, and can increase learning activities and motivation. Therefore, it is necessary to develop lecture material in other forms, namely constructivism-oriented modules with valid, practical and effective mind maps for lectures on plant physiology at LAIN Kerinci. This research is a development research using a 4D model. Stages carried out are 1) defining, 2) designin, 3) developing, and disseminating. After being designed, the module is validated by 4 validators. For practicality, the module was tested on students in semester VI B Biology Education Study Program IAIN Kerinci. Lecture activities were observed by 1 observer. Through data analysis, data obtained from validity, practicality, and effectiveness. Data obtained were analyzed qualitatively and quantitatively. The results of the validation show that constructivism-oriented modules equipped with mind maps are very valid in terms of content and constructs. Based on practical data analysis, it is obtained that constructivist oriented modules equipped with mind maps are very practical to be used in lectures in Plant Physiology, it can be seen from the implementation of planned and time-efficient lectures, clear module instructions, and module content according to the needs of students.
\end{abstract}

Keywords: Modules, Plant Physiology, Constructivism, Mind Maps

\begin{abstract}
Abstrak: Mahasiswa membutuhkan suatu bahan perkuliahan yang dapat membantu dan memudahkan mereka dalam perkuliahan, serta dapat meningkatkan aktivitas dan motivasi belajar. Karena itu, perlu dikembangkan bahan perkuliahan dalam bentuk lain, yakni modul berorientasi konstruktivisme dilengkapi peta pikiran yang valid, praktis dan efektif untuk perkuliahan Fisiologi tumbuhan di IAIN Kerinci. Penelitian ini adalah penelitian pengembangan dengan menggunakan model 4D. Tahapan yang dilakukan yaitu 1) pendefinisian (define), 2) perancangan (design), 3) pengembangan (develop), dan penyebaran (dissiminate). Setelah dirancang, modul divalidasi oleh 4 orang validator. Untuk praktikalitas, modul diuji cobakan kepada mahasiswa semester VI B Progam Studi Pendidikan Biologi IAIN Kerinci. Kegiatan perkuliahan diamati oleh 1 orang observer. Melalui analisis data diperoleh data validitas, praktikalitas, dan efektivitas. Data yang diperoleh dianilisis secara kualitatif dan kuantitatif. Hasil validasi menunjukkan bahwa modul berorientasi konstruktivisme dilengkapi peta pikiran sudah sangat valid dari segi isi dan konstruk. Berdasarkan analisis data praktikalitas diperoleh bahwa modul berorientasi konstrutivisme dilengkapi peta pikiran sudah sangat praktis digunakan dalam perkuliahan Fisiologi Tumbuhan, terlihat dari pelaksanaan perkuliahan yang sesuai rencana dan efisien waktu, petunjuk modul jelas, isi modul sesuai dengan kebutuhan mahasiswa.
\end{abstract}

Kata kunci: Modul, Fisiologi Tumbuhan, Kontruktivisme, Peta Pikiran 


\section{PENDAHULUAN}

Fisologi Tumbuhan merupakan ilmu yang mempelajari tentang proses, fungsi, dan aktivitas tumbuhan dalam menjaga dan mengatur kehidupannya. Di IAIN Kerinci Fisiologi Tumbuhan merupakan salah satu mata kuliah keilmuwan dan keterampilan yang harus dipelajari dengan total 2 SKS oleh mahasiswa Program Studi Pendidikan Biologi IAIN Kerinci. Berdasarkan observasi yang dilakukan peneliti di IAIN Kerinci terhadap proses perkuliahan Fisiologi Tumbuhan, diperoleh keterangan bahwa dalam perkuliahan kemampuan mahasiswa masih belum maksimal. Hal ini dibuktikan dengan masih banyaknya nilai ujian akhir Fisiologi Tumbuhan mahasiswa Program Studi Pendidikan Biologi IAIN Kerinci yang belum mencapai kriteria yang telah ditetapkan oleh IAIN Kerinci yaitu nilai B dengan skor minimal 70.

Hasil wawancara yang dilakukan peneliti dengan dosen pengampu mata kuliah Fisiologi Tumbuhan Program Studi Pendidikan Biologi IAIN kerinci diperoleh keterangan dalam pelaksanaan perkuliahan Fisiologi Tumbuhan mahasiswa mengalami kesulitan memahami materi, memecahkan masalah dan membangun konsep sendiri serta belum memiliki bahan ajar yang mampu menuntun mahasiswa untuk belajar mandiri sehingga perkuliahan menjadi kurang efektif karena hanya berpusat pada dosen.

wawancara peneliti dengan beberapa mahasiswa program studi Pendidikan Biologi IAIN Kerinci, diperoleh keterangan bahwa dalam memperoleh informasi mahasiswa cenderung hanya mengharapkan informasi dari dosen, dosen dalam memberikan informasi menggunakan metode konvensional yaitu ceramah, mahasiswa hanya mendengarkan dan mencatat penjelasan dari dosen sehingga mahasiswa merasa bosan dan kurang termotivasi untuk belajar. Bahan ajar yang digunakan hanya buku teks yang memuat materi yang panjang dan cenderung berbelit-belit, sehingga mahasiswa sulit memahami materi yang disajikan di dalamnya. Disamping itu, mahasiswa menjadi kurang informatif karena butuh waktu lama untuk mengkonstruksi pengetahunanya sehingga apa yang dituntut oleh kompetensi yang harus dicapai dalam kurikulum yaitu mahasiswa pada akhirnya dapat meningkatkan keterampilan prosesnya belum dapat terpenuhi.

Untuk mengatasi masalah tersebut, perlu pengembangan bahan ajar yang dapat membantu dalam meningkatkan pemahaman dan motivasi mahasiswa, serta bahan ajar yang dapat merangsang mahasiswa untuk lebih aktif. Pemilihan dan penggunaan bahan ajar yang tepat dalam perkuliahan merupakan faktor yang sangat penting dalam mengarahkan 
mahasiswa untuk memperoleh pengalaman belajar. Dalam hal ini berupa bahan ajar dalam bentuk modul.

Untuk mendukung peningkatan pemahaman mahasiswa maka modul ini dibuat berorientasi konstruktivisme. Dalam proses perkuliahan penggunaan otak kanan dan otak kiri haruslah seimbang untuk mendapatkan hasil yang optimal. Peta pikiran dapat membantu mahasiswa dan dosen dalam proses perkuliahan di kelas dengan meringkas bahan yang demikian banyak menjadi beberapa lembar peta pikiran saja, yang jauh lebih mudah untuk dipelajari dan diingat mahasiswa. Dengan peta pikiran seluruh informasi-informasi kunci dan penting dari setiap bahan perkuliahan dapat diorganisir dengan menggunakan struktur radian yang sesuai dengan mekanisme kerja alami dari otak sehingga lebih mudah untuk dipahami dan diingat.

\section{METODE}

Jenis penelitian adalah penelitian dan pengembangan menggunakan 4-D Model dengan tahapan sebagai berikut: Define, Design, Develop tahap Disseminate tidak dilakukan. Subjek uji coba yaitu mahasiswa Program Studi Pendidikan Biologi IAIN Kerinci semester VI. Subjek uji coba uji praktikalitas yaitu kelas VIB. Modul pembelajaran ini dikembangkan dengan model pengembangan 4-D (four D) models, yang terdiri dari 4 tahap. Tahap-tahap itu adalah pendefinisisan (define), perancangan (design), pengembangan (develop). Penelitian ini hanya dilakukan sampai tahap develop saja.

\section{Tahap pendefinisian (define)}

Pelaksanaan penelitian dimulai dengan tahap define. Pada tahap ini ini dilakukan penetapan syarat-syarat pembelajaran dengan menganalisis standar kompetensi dan batasan materi pelajaran yang akan diajarkan oleh dosen berdasarkan standar isi kurikulum. Pada tahap ini dilakukan analisis silabus, wawancara dengan dosen dan analisis mahasiswa.

\section{Tahap perancangan (design)}

Tahap design bertujuan membuat modul Fisiologi Tumbuhan sesuai dengan standar kompetensi, kompetensi dasar, indikator dan tujuan pembelajaran. Tahap ini terdiri atas 3 langkah utama, di antaranya: 1) merancang kerangka modul; 2) menyusun kerangka modul; 3) menyusun program terperinci yang meliputi semua komponen modul. 
3. Tahap pengembangan (develop)

Tahap develop bertujuan menghasilkan suatu bentuk modul pembelajaran Fisiologi Tumbuhan yang telah direvisi sesuai dengan saran validator, sehingga diperoleh bentuk akhir modul yang dapat digunakan dalam uji coba. Tahap ini terdiri dari uji validitas, uji praktikalitas modul.

\section{HASIL}

\section{Tahap Pendefinisian (define)}

Pada tahap ini ini dilakukan penetapan syarat-syarat pembelajaran dengan menganalisis standar kompetensi dan batasan materi pelajaran yang akan diajarkan oleh dosen berdasarkan standar isi kurikulum. Pada tahap ini dilakukan analisis silabus, wawancara dengan dosen dan analisis mahasiswa.

a. Analisis silabus

Berdasarkan analisis yang telah dilakukan terhadap SK dan KD yang terdapat dalam silabus, maka SK dan KD dijabarkan menjadi indikator, dan ditentukan tujuan pembelajarannya.

b. Wawancara dengan Dosen

Dari hasil wawancara dengan dosen didapat informasi bahwa perkuliahan Fisiologi Tumbuhan selama ini hanya terpusat pada dosen, mahasiswa kurang merespon penjelasan dari dosen. Minat dan motivasi mahasiswa rendah sehingga menyebabkan hasil belajar mahasiswa rendah. Bahan perkuliahan yang dimaksud dapat berupa modul. Dengan bantuan modul, mahasiswa mendapat tambahan referensi selain dari dosen dan buku teks. Modul dapat melatih mahasiswa untuk belajar mandiri.

Sampai saat ini selain buku teks, di IAIN Kerinci belum ada bahan perkuliahan yang digunakan untuk membantu mempermudah mahasiswa dalam memahami materi perkuliahan Fisiologi Tumbuhan. Modul diharapkan dapat memotivasi dan merangsang aktivitas berpikir mahasiswa dalam menggali dan memaksimalkan potensi yang mereka miliki.

c. Analisis Mahasiswa

Analisis mahasiswa dilakukan untuk mengidentifikasi karekteristik mahasiswa. alat untuk menganalisis mahasiswa dapat menggunakan Alat Ungkap Masalah (AUM). 


\section{Tahap Perancangan (design)}

Tahap ini terdiri atas 3 langkah utama, berikut ini.

a. Merancang Kerangka Modul

Materi-materi dalam Fisiologi Tumbuhan disajikan dengan bahasa yang mudah dipahami dan dalam bentuk gambar yang menarik perhatian mahasiswa. Penggunaan gambar berwarna memberikan beberapa manfaat yaitu mahasiswa dapat mengelompokkan konsep, menunjukkan hubungan antar bagian-bagian informasi yang terpisah.

b. Menyusun Kerangka Modul

1) Menentukan Topik

2) Menentukan urutan topik-topik dalam modul

c. Menyusun Program Terperinci yang Meliputi Semua Komponen Modul Sebagai berikut ini. 1) Cover

Cover menggambarkan isi dari modul berorientasi konstruktivisme dan dilengkapi peta pikiran yang dirancang. Cover modul dibuat dengan tampilan semi formal, dengan kombiansi warna hijau, putih dan orange. Pada cover terdapat gambar tumbuhan. Gambar pada cover depan modul ini dapat merefleksikan isi modul. Jenis font yang digunakan pada cover bervariasi.

2) Kata pengantar

Kata pengantar berisi ucapan syukur dan tujuan penulis merancang modul berorientasi konstruktivisme dan dilengkapi peta pikiran. Kata pengantar dibuat dengan kata-kata yang tidak formal dan mudah dipahami mahasiswa.

3) Petunjuk Penggunaan Modul

Petunjuk penggunaan modul berisi penjelasan kepada mahasiswa tentang bagaimana cara menggunakan modul berorientasi konstruktivisme dan dilengkapi peta pikiran serta untuk dosen agar lebih mudah membimbing mahasiswa dalam kegiatan perkuliahan.

4) Daftar isi

Daftar isi memudahkan mahasiswa untuk mengetahui halaman materi yang diinginkan.

5) Sampul judul

Setiap modul diberi sampul dengan gambar yang berbeda. Salah satu unsur modul berorientasi konstruktivisme dilengkapi peta pikiran adalah orientasi, yakni memberikan kesempatan pada mahasiswa untuk mengembangkan motivasi dalam mempelajari suatu topik. 
6) Tujuan pembelajaran

Tujuan pembelajaran dipaparkan dengan bahasa sederhana sehingga mudah dipahami mahasiswa.

7) Pendahuluan

Pendahuluan bertujuan untuk memberikan ringkasan secara umum kepada mahasiswa tentang materi yang akan dibahas pada modul tersebut. Selain itu juga dijelaskan tentang hubungan materi pada modul tersebut dengan materi selanjutnya, dan pada bagian ini terdapat uraian cerita untuk mengaktifkan pengetahuan awal mahasiswa.

8) Materi

Uraian materi yang terdapat pada setiap modul/kegiatan belajar dimaksud untuk memberikan penjelasan yang lengkap tentang materi yang akan dipelajari mahasiswa.

9) Lembar latihan.

Bagian ini memuat unsur konstruktivisme yakni rekonstruksi ide (menyusun gagasan baru dengan cara diharapkan dengan ide yang sudah ada).

10) Kesimpulan

Kesimpulan bertujuan untuk mengulas secara ringkas kembali materi yang telah dipelajari dan memberikan beberapa penekanan pada konsep penting selama belajar.

11) Kunci Jawaban

Kunci jawaban merupakan dasar untuk mahasiswa mencocokkan jawaban yang dibuat mahasiswa pada latihan yang terdapat pada modul.

12) Daftar Pustaka

Daftar pustaka dalam modul ini merupakan sumber materi dan gambar yang digunakan dalam modul.

\section{Tahap Pengembangan}

a. Hasil validasi modul

Data hasil validasi modul berorientasi kontruktivisme dilengkapi peta pikiran lebih jelasnya dapat dilihat pada tabel 1 .

Tabel 1. Hasil Validasi Modul

\begin{tabular}{|c|c|c|c|}
\hline No & Aspek & Nilai & Kategori \\
\hline 1 & Didaktik & 87,5 & Sangat Valid \\
\hline 2 & Isi & 95,8 & Sangat Valid \\
\hline 3 & Penyajian & 94,4 & Sangat Valid \\
\hline 4 & Bahasa & 80 & Valid \\
\hline & Jumlah & 89,4 & Sangat Valid \\
\hline
\end{tabular}


Dari data dapat dilihat bahwa nilai rata-rata untuk semua indikator yaitu 89,4\% dengan kategori sangat valid.

b. Observasi keterlaksanaan perkuliahan

Data hasil observasi keterlaksanaan perkuliahan dengan menggunakan modul berorientasi konstruktivisme dilengkapi peta pikiran dapat dilihat pada Tabel 2.

Tabel 2. Hasil Observasi Keterlaksanaan Perkuliahan

\begin{tabular}{llc}
\hline No & Pertemuan & Rata-rata \\
\hline 1 & Pertemuan I & 84 \\
\hline 2 & Pertemuan II & 84 \\
\hline 3 & Pertemuan III & 88 \\
\hline 4 & Pertemuan IV & 84 \\
\hline 5 & Pertemuan V & 80 \\
\hline & Jumlah & 84 \\
\hline
\end{tabular}

Berdasarkan hasil observasi yang telah dilakukan oleh dosen Fisiologi Tumbuhan diperoleh bahwa selama perkuliahan dengan menggunakan modul tidak terdapat kendala yang bearti yang dapat menghambat kegiatan perkuliahan. Perkuliahan dengan menggunakan modul berorientasi konstruktivisme dilengkapi peta pikiran sudah terlaksana sesuai dengan SAP yang telah dirancang.

c. Hasil praktikalitas modul oleh dosen

Data hasil praktikalitas modul dapat dilihat pada tabel 3.

Tabel 3. Hasil Praktikalitas Modul oleh Dosen.

\begin{tabular}{llcl}
\hline No & \multicolumn{1}{c}{ Indikator } & Rata-rata & Kategori \\
\hline 1 & Kepraktisan penggunaan & 92,5 & Sangat praktis \\
\hline 2 & Kesesuian waktu & 90 & Sangat praktis \\
\hline 3 & Kesesuaian ilustrasi & 80 & Sangat praktis \\
\hline 4 & Bahasa & 87,5 & Sangat praktis \\
\hline \multicolumn{2}{c}{ Rata-rata } & 87,5 & Sangat praktis \\
\hline
\end{tabular}

Hasil penilaian praktikalitas oleh dosen secara keseluruhan terhadap modul Fisiologi Tumbuhan berorientasi konstruktivisme dilengkapi peta pikiran yang dikembangkan yaitu rata-rata setiap indikator 80 sampai $92,5 \%$ dengan kategori praktis sampai sangat praktis.

d. Hasil praktikalitas oleh mahasiswa

Tabel 4. Hasil Praktikalitas oleh Mahasiswa

\begin{tabular}{llcl}
\hline No & \multicolumn{1}{c}{ Indikator } & Rata-rata & Kategori \\
\hline 1 & Bentuk modul & 94,4 & Sangat praktis \\
\hline 2 & Isi modul & 89,4 & Sangat praktis \\
\hline 3 & Kepraktisan & 92 & Sangat prakits \\
\hline & Rata-rata & 91,9 & Sangat praktis
\end{tabular}


Hasil praktikalitas modul oleh mahasiswa diperoleh rata-rata nilai setiap indikator berkisar antara 89, 4\% sampai 92\% dengan kategori sangat praktis.

\section{PEMBAHASAN}

1. Validasi Modul

Berdasarkan uji validitas, validator menyatakan modul berorientasi konstruktivisme dilengkapi peta pikiran pada mata kuliah Fisiologi Tumbuhan yang peneliti rancang sudah sangat valid dengan rata-rata 89,4\%. Modul berorientasi konstruktivisme dilengkapi peta pikiran sangat valid karena modul ini disusun sesuai dengan standar kompetensi, dan kompetensi dasar yang telah ditetapkan. Materi yang disajikan dalam modul berorientasi konstruktivisme dilengkapi peta pikiran ini telah sesuai dengan indikator pembelajaran sehingga semua indikator dapat tercapai. Hal ini sejalan dengan pendapat Bandono (2009) yang menyatakan bahwa dalam menyusun bahan ajar harus sesuai dengan kurikulum yang berlaku.

\section{Praktikalitas Modul}

a. Observasi keterlaksanaan perkuliahan

Hasil observasi keterlaksanaan perkuliahan dengan modul berorientasi konstruktivisme dilengkapi peta pikiran diperoleh nilai rata-rata yaitu 84\% dengan kategori sangat baik karena selama perkuliahan tidak terdapat masalah yang bearti. Mahasiswa mudah menggunakan modul. Kesimpulannya proses perkuliahan dengan menggunakan modul berorientasi konstruktivisme dilengkapi peta pikiran dapat menciptakan situasi kelas yang mendorong mahasiswa untuk saling bertanya, menjawab dan mengeluarkan pendapat, terjadinya interaksi antara mahasiswa. Selain itu, dengan perkuliahan menggunakan modul dapat menstimulasi mahasiswa dengan baik dalam meningkatkan motivasi mahasiswa dalam belajar serta dapat mengembangkan kemandirian dan kreativitas dalam memahami materi. Hal ini sejalan dengan pendapat Anwar (2008) dalam perkuliahan akan berjalan dengan baik apabila kondisi belajar mendukung untuk proses perkuliahan.

\section{b. Praktikalitas Modul Oleh Dosen}

Berdasarkan hasil uji coba praktikalitas modul oleh dosen menunjukkan bahwa modul berorientasi konstruktivisme dilengkapi peta pikiran pada mata kuliah Fisiologi Tumbuhan diperoleh rata-rata 87,8\% dengan katergori sangat praktis. Hal ini, menunjukkan bahwa dengan adanya modul berorientasi konstruktivisme dilengkapi peta pikiran pada mata kuliah 
Fisiologi Tumbuhan di Prodi Pendidikan Biologi STAIN Kerinci Semesester VI dapat memudahkan dosen dalam proses perkuliahan serta memiliki waktu yang lebih efisien. Modul dapat memfasilitasi mahasiswa untuk belajar mandiri, mengurangi beban dosen dalam menjelaskan materi perkuliahan berulang-ulang, dan dapat mengubah peran dosen dari seorang pengajar menjadi fasilitator.

Hal ini sesuai dengan yang dikemukakan oleh Pannen dan Purwanto (2005), sebagai dosen yang professional diharuskan dapat membuat dan mengembangkan bahan ajar sendiri, ini bermanfaat untuk memperoleh bahan ajar yang sesuai dengan kurikulum dan kebutuhan belajar, tidak tergantung kepada buku teks yang ada, bahan ajar menjadi lebih kaya karena dikembangkan dengan menggunakan berbagai referensi, menambah khasanah pengetahuan dan pengalaman dosen dalam menulis bahan ajar.

c. Praktikalitas modul oleh mahasiswa

Hasil uji praktikalitas modul oleh mahasiswa menunjukkan rata-rata nilai 91,9\% dengan kategori sangat praktis. Dengan demikian rata-rata praktikalitas modul beorientasi konstruktivisme dilengkapi peta pikiran oleh mahasiswa dinyatakan sangat praktis karena modul dapat meningkatkan minat mahasiswa dalam belajar.

Mahasiswa merasa tertarik menggunakan modul berorientasi konstruktivisme dilengkapi peta pikiran karena mahasiswa belum pernah menggunakan modul dalam perkuliahan dan penyampaian materi dalam modul didukung dengan gambar dan peta pikiran. Sejalan dengan pendapat Sardiman (2001) mengatakan bahwa sebuah gambar berbicara lebih banyak daripada seribu kata. Lebih lanjut Sadiman mengungkapkan bahwa gambar memiliki beberapa kelebihan diantaranya gambar dapat mengatasi keterbatasan pengamatan. Sehingga dengan adanya gambar-gambar pada modul berorientasi konstruktivisme dilengkapi peta pikiran dapat membantu mahasiswa lebih mudah memahami materi yang dipelajarinya.

Penggunaan modul berorientasi konstruktivisme dilengkapi peta pikiran dalam perkuliahan memunculkan ketertarikan mahasiswa untuk belajar Fisiologi Tumbuhan, karena modul yang dikembangkan menggunakan bahasa yang mudah dipahami. Hal ini sesuai dengan apa yang diungkapkan oleh Bandono (2009) bahwa dengan menggunakan modul dengan bahasa yang baik membantu mahasiswa lebih cepat memahami materi, merasa senang, santai, dan tidak merasa tegang dalam mengikuti perkuliahan. Dengan adanya peta pikiran mengakibatkan mahasiswa tertarik menggunakan modul karena dengan peta pikiran dapat menambah daya ingat. Sejalan dengan pendapat Yoga (2011) bahwa peta pikiran dapat 
membantu mahasiswa dalam proses perkuliahan karena dengan peta pikiran mahasiswa dapat meringkas uraian materi menjadi beberapa lembar materi sehingga mudah untuk diingat.

\section{PENUTUP}

Modul berorientasi konstruktivisme dilengkapi peta pikiran pada mata kuliah Fisiologi Tumbuhan yang telah dikembangkan mempunyai validitas dengan kategori sangat valid, praktikalitas dengan kategori sangat praktis dan efektivitas dengan kategori sangat efektif.

\section{REFERENSI}

Buzan, T. (2008). Peta pikiran Untuk Meningkatkan Kreativitas. Jakarta: Gramedia Pustaka Utama.

Depotter, B \& Mike, H. (2010). Quantum Learning. Bandung: Kaifa.

Djaali. (2011). Psikologi Pendidikan. Jakarta: PT. Bumi Aksara.

Jones, et al. (2012). The Effects of Mind Mapping activities on Students' Motivation. International Journal for The Scholarship Of teaching And learning. Vol. 6. No. 1(January 2012). Georgia Southerm University.

Gunawan. (2013). "Mendambakan Perguruan Tinggi Berkualitas" Jurnal 2013. Guru Besar FMIPA ITB Bandung.

Hayati, I., \& Sujadi, E. (2018). Perbedaan Keterampilan Belajar Antara Siswa IPA dan IPS. Tarbawi : Jurnal Ilmu Pendidikan, 14(1), 1-10. doi:10.32939/tarbawi.v14i1.250

Novallyan, D. (2012). "Pengembangan Modul Pembelajaran Pada Mata Kuliah Biologi Sel di Perguruan Tinggi”. Tesis. Padang: Program Pascasarajana Universitas Negeri Padang.

Nurhadi \& Agus, G. S. (2003). Pembelajaran Konstektual (Contextual Taeching and Learning) dan Penerapannya dalam KBK. Malang: Universitas Negeri Malang.

Prayitno, et al. (2002). Alat Ungkap Masalah PTSDL Format 1-PT. Padang: Program Studi Bimbingan Konseling Jurusan Psikologi Pendidikan dan Bimbingan FIP IKIP Padang.

Prayitno. (1997). Pedoman AUM PTSDL. Padang: UNP.

Purnawati. P. (2010). "Pengaruh Pendekatan Konstruktivisme dalam Pembelajaran Kimia terhadap Kemampuan Berpikir Kreatif Mahasiswa". Jumal. 2010. UIN Syarif Hidayatullah Jakarta. 
Rangkuti, siti maya sari, Nindi, \& Dian. (2010). Penerapan Metode Belajar Menggunakan Mind Map untuk Membangun Cara Berpikir Sistematis Siswa Sekolah Dasar. PKM gagasan tertulis. Bogor: Institut Pertanian Bogor.

Ramli, M. (2006). Pembelajaran Sains Menyenangkan dengan Metode Konstruktivisme. Jurnal Teori Pembelajaran Konstruktivisme. 2006. Vol 1. UIN Syarif Hidayatullah Jakarta FITK.

Riyanto, Y. (2009). Paradigma Baru Pembelajaran. Jakarta: Kencana.

Sugiyono. 2011. Metode Penelitian Pendidikan Pendekatan Kuantitatif, Kualitatif dan RéD. Bandung: Alfabeta.

Sujadi, E. (2017). Penerapan Pendidikan Karakter Cerdas Format Kelompok Untuk Meningkatkan Nilai Kejujuran Mahasiswa Bimbingan Konseling Islam (BKI) Institut Agama Islam Negeri (IAIN) Kerinci. Tarbawi : Jurnal Ilmu Pendidikan, 13(1), $97-$ 108Trianto. 2010. Model Pembelajaran Terpadu: Konsep, Strategi dan Implementasinya dalam KTSP. Jakarta: Bumi Aksara.

Sujadi, E., \& Wahab, M. (2018). Strategi Coping Korban Bullying. Tarbawi : Jurnal Imu Pendidikan, 13(2), 21-32.

2007. Model-Model Pembelajaran Inovatif Berorientasi Konstruktivistik, Jakarta: Prestasi Pustaka Publisher.

Vembrianto. 1981. Pengajaran Modul. Yogyakarta: Paramita.,121-140.

Wahyuningsih, A. N. 2011. Pengembangan Media Komik Bergambar Materi Sistem Saraf Untuk Pembelajaran yang Menggunakan Strategi PQ4R. Jurnal PP. Vol. 1. No. 2. 